\title{
Is home the best place to be old? The changing geography of responsibilities in the care for elderly.
}

\author{
De Lange, Frits \\ Stellenbosch University \\ fdelange@pthu.nl
}

\begin{abstract}
In this article, the changing geography of care for the elderly in today's society is mapped out in (1) its consequences for the meaning of "home" for frail elderly and (2) for the distribution of care responsibilities. Two current ideas that are criticized are that (1) home is always the best place to be (and therefore also the preferred place to receive care), and (2) that one has stronger ethical obligations to people who live in one's neighbourhood, because of their proximity. Together with the so-called ethics of care, care is considered a fundamental societal practice, and the distribution of caring responsibilities a primary ethical question. Care responsibility, it is argued, is never a natural given, but must be negotiated in every situation and different context anew. In following moral philosopher Robert Goodin, the article concludes that responsibility in long-term relationships between frail parents and adult children not proximity is decisive for assigning responsibility, but the parents' specific vulnerability.
\end{abstract}

Key words

Ageing; care; ethics of care; responsibility

\section{Introduction}

In the last decades in the Netherlands, as in other former welfare states, the conviction became state policy that the elderly should live at their homes as long as possible, and, if dependent on care, should consider their adult children or neighbourhood responsible for delivering that care. The idea behind this policy is not only that "ageing in place" is more cost-effective, but also that old people prefer to live and receive care at home. 
This neoliberal policy leaves the idea behind - dominant in welfare states of the late $20^{\text {th }}$ century, but also in non-western, and (post-) socialist societies that taking care of the elderly is a public and collective responsibility. ${ }^{1}$

In this article, I want (1) to ask what the meaning of "home" is for frail elderly. Is home (still) for them the best place to be? I suppose that a romantic misunderstanding of "home" comes into play here. (2) I doubt whether adult children always have a first responsibility for the care of their aged parents. Care responsibility, I will argue here, is never a natural given, but must be negotiated anew in every situation and different context. I will offer some arguments for a "deprivatization" - or: de-particularization - of care for the elderly people.

In answering these questions, I draw on two theoretical propositions: (1) Together with the so-called ethics of care, I consider care a fundamental societal practice, and distribution of caring responsibilities as the primary ethical question. Care should not be regarded as a commodity, subject to market mechanisms. Care is not a private activity in the margin of society, to be delegated in particular to women, but a collective responsibility. ${ }^{2}$ (2) With Margaret Urban Walker, I also consider morality as a social practice in which what is good and who is responsible for doing good - and when, where and to whom - is expressed in relationships, identities and values, and is assessed in ongoing dialogue and negotiations. There is no such thing as pure moral knowledge obtained by pure reflection. With Walker, I want to stay away from a juridical-theoretical understanding of ethics

1 " $[\mathrm{N}]$ eoliberalism is predominantly associated with the ongoing shift from public to private ownership that began in the 1980s; the shift of risk from the state or government to the individual; the continuing attempt to downsize or privatize established social care; the changes in governmental support for health and well-being; the increasing income inequality; and, most significantly, an increasing focus on the individual as the locus of social action and motive.' (Robert L. Rubinstein and Kate de Medeiros, "Successful Aging," Gerontological Theory and Neoliberalism: A Qualitative Critique," The Gerontologist 55, no. 1 (2015): 34-42, 36). Concerning post-socialist societies, cf. Christine Milligan, There's No Place Like Home: Place and Care in an Ageing Society (Farnham: Ashgate, 2009), 55: "Within countries formerly part of the Soviet Republic, the historical legacy of collective responsibility meant that until relatively recently, (basic) long-term care for frail and vulnerable groups was provided within state-run institutional settings."

2 Cf. Joan Tronto, Moral Boundaries. A political argument for an ethic of care (New York: Routledge, 1993) and idem, Caring democracy. Markets, equality and justice (New York: New York University Press, 2013). 
and defend - what she calls an expressive-collaborative concept of ethics. In that approach, responsibility is a dialogical practice, not an ethical principle. $^{3}$

The two current ideas that I want to criticize in this paper are that (1) home is always the best place to be (and therefore also the preferred place to receive care), and (2) that one has stronger ethical obligations to people who live in one's neighbourhood, because of their proximity.

My article is written mainly from the perspective of elderly people in current Dutch society, so it has a very limited, contextual scope. However, I think my reflection on the meaning of "home", and my approach to responsibility transcends that context and may inform other discourses as well. The group of frail seniors is expanding worldwide. Often people in the West have a romanticized idea of the life older people lead in societies with a community-oriented ethics, filled with love and respect. However, reality often proves otherwise. "Economically, older people experience difficulty working in old age due to health problems. Only one in five have access to pensions. In the HIV/Aids-ridden areas, older people are even more vulnerable. They are often left with grandchildren whose parents have died because of HIV/Aids or violent conflicts. Without support, not only they, but also their grandchildren are facing serious problems."4 Due to global urbanization processes, traditional, rural family and community structures rapidly erode and impede the elderly to rely on the support of their adult children and their families.

In my first section, I shall sketch the changing landscape of care in present Dutch society. In the next one, I shall go into the question of what living at home means for frail, care-dependent elderly. In a final section, I conclude with an ethical reflection on responsibility in the context of care, and on the question what a fair distribution of responsibilities then means.

3 Margaret Urban Walker, Moral Understandings. A Feminist Study in Ethics (New York and London: Routledge, 1998).

4 Global aging is changing the world. World Granny report 2004-2016 http://www. unightforgranny.nl/wp-content/uploads/2018/05/Jaarverslag-2004-2016.pdf 


\section{The changing landscape of care}

The spatial metaphor of landscape is chosen deliberately. How people care for each other depends on where they live. Who cares for whom and how, depends on its where. ${ }^{5}$ This applies globally, nationally, and regionally, but also on a micro-level. Ageing is not an abstraction. Growing old in medieval times or in the $21^{\text {st }}$ century, in the Netherlands or in Sub-Saharan Africa, in urban or in rural contexts, owning a house (big, small, old, new), having children, grandchildren around - determine whether and how you are being cared for. Where you live can kill you is the subtitle of a recent book of Clare Bambra, who is doing research on how health inequalities are influenced by the place one lives. "Geography is a matter of life and death", she writes. ${ }^{6}$ Where one lives, determines one's socio-economic status and this, in turn, how old you will grow, and how. Bambra supplies convincing evidence that "the demographic (age, sex and ethnicity), health behaviour (smoking, alcohol, physical activity, diet, drugs) and socioeconomic (income, education, occupation) profile of the people within a community determines its health outcomes: poor people result in poor places."7

The landscape of care is changing: For centuries, the elderly were taken care of in and by their physical neighbourhood, by their family living under the same roof, or next-door neighbours. Care was organized territorially. Physical proximity determined responsibility. In emerging economies without a pension system or institutionalized healthcare, children still count as old age provision. ${ }^{8}$ The two basic aspects of care, caring about, being attentive to someone's needs, and caring for, the concrete activities

5 For the "geography of care" as a sub discipline within geography, cf. Victoria Lawson, "Geographies of Care and Responsibility". Annals of the Association of American Geographers 97, no. 1 (2007): 1-11.

6 Bambra is Professor of Public Health Geography in Newcastle, UK. Clare Bambra, Health Divides. Where You Live Can Kill You (Bristol: Policy Press, 2016), 23: 'Place both creates and contains social, economic and political relations as well as physical resources. Spatial inequalities in health are therefore a result of a complex mix of economic, social, environmental and political processes - coming together in particular places. Places can be health-promoting (salutogenic) or health-damaging (pathogenic).'

7 Bambra, Health Divides, 97f.

8 Globally about 100 countries have some kind of pension system. In most lower and middle income nations however, there is none. Cf. "Watch. Protection in Old Age. HelpAge International”. [Online]. Available: http://www.pension-watch.net/ [Accessed: February 1, 2018]. 
of meeting someone needs, then belong together and are in the hands and hearts of the same persons. Informal and formal care, community care and professional care are not differentiated. ${ }^{9}$

With the revolutionary increase in the number of elderly and their life expectancy, combined with developments in medical technology, care for the old underwent an exponential expansion in both extent and complexity, which affects the geography of care in a fundamental way. ${ }^{10}$ Health care is in the process of being medicalized and technologized, and is at the same time becoming the object of commodification. Besides physical and territorial space, other spaces are created with their own dynamics of distance and proximity, strongly connected to processes of modernization and globalization. ${ }^{11}$ Communication technology and internet are creating global forms of proximity (for instance Face Timing with your grandchildren down under) and local distance (not knowing what happens two streets away in your neighbourhood). The physical place where you live is only one place among others, and not always the most important one.

This also affects the lifeworld of elderly and the content and organization of the way they are cared for. The so-called welfare state, as developed in

9 Milligan, No Place like Home, $14 \mathrm{ff}$.

10 The societal challenge of an aging population is not only a Northern hemisphere affair. The world population is rapidly getting older. This 'demographic transition' is driven by two factors: increased life expectancy and declining fertility rates. Already over sixty percent of the world's aged population lives in developing countries, and this will increase to seventy-five percent by 2025 and eighty-five percent by 2050, according to the United Nations Population Division. The 80-plus age group makes up the fastest growing segment of the population; its share of the over- 60 population will increase from twelve percent to nineteen percent by 2050.' (Frits de Lange, "The Dignity of the Old: Towards a Global Ethic of Ageing”, International Journal of Public Theology 3, no.2 (2009): 203-220, 204).

11 Arjun Appadurai, Modernity at large: Cultural dimensions of Globalisation (Minneapolis: University of Minnesota Press, 1996) distinguishes in the globalization process, five, for the largest part imagined worlds or symbolic spaces: ethnoscape, the physical world of travelers, tourists, refugees, migrants etc.; technoscape, the global configuration of technology, both mechanical and informational, financescape, the flows of global; mediascape, the electronic (social) media; ideoscape, de circulation of ideals and ideologies, generating political power. (Quoted by Martin Hyde \& Paul Higgs, Ageing and Globalisation (Bristol: Policy Press 2016), 38). Marc Augé introduced the distinction between space and place, as spaces respectively without and with meaning, arguing that globalization resulted in an increase of space as non-place (Marc Augé, Non-places. Introduction to an Anthropology of Supermodernity (London-New York: Verso, 1995). 
Western societies post-World War II, radically dissociated itself from the idea that care for the elderly should take place at home by the family. Elderly care became a state-governed, public responsibility in the form of elderly pensions and social security, covering - as was the case in the Netherlands with the so-called Algemene Wet Bijzondere Ziektekosten (AWBZ) simultaneously the costs of housing, living and medical care. Care for the old and very old became institutionalized in a concrete physical place, the retirement or nursing home, where even the informal para- and nonmedical care was organized according to a medical code and regime.

After the welfare state collapsed and was replaced by neo-liberal policies, this model vanished. Since then, as it happened in the Netherlands, public retirement homes have been closed at a rapid pace. Access to a nursing home is reserved now only for those elderly who need intensive 24-hours care. ${ }^{12}$ Though there are relative differences in their policy, all EU countries without exception are guided by the ideal of "successful" or "active ageing", which expresses a neo-liberal political ideology: it implies three aspects. (1) Care is primarily a personal and private responsibility, to be organized by individuals within their own social network. The family therefore is the primary locus of care. (2) Formal care is regarded as a commodity, regulated by the market. When you need to be looked after, you pay for it. (3) The state stimulates and mobilizes on both a national and local level the financial independence and social self-reliance of its elderly citizens. ${ }^{13}$

This means that the focus in the geography of care is shifting again towards home and the proximate physical environment. So it seems that care is back again were it once began: after a short period (a historical mistake?) of elderly care as a collective responsibility, it returns where nature seems to have meant it: at home, in the family.

This picture however, does not consider some important developments, essential for a fair distribution of responsibilities in the geography of care.

12 Cretien van Campen, Jurjen Iedema, Marjolein Broese van Groenou, Dorly Deeg, Langer Zelfstandig. Ouder worden met hulpbronnen, ondersteuning en zorg. (Den Haag: Sociaal en Cultureel Planbureau, 2017). The nursing home represents the end of the healthcare chain: the average stay until death in 2016 in a Dutch nursing home counted 430 days. ("Feiten en cijfers over de verpleeghuiszorg, Actiz 2016". [Online]. Available: https://www. actiz.nl/stream/160715-feiten-en-cijfers-verpleeghuiszorgdef.pdf [Accessed: 1 February 2018].

13 Virpi Timonen, Beyond Successful and Active Ageing. A Theory of Model Ageing (Bristol: Policy Press, 2017). 
First: it neglects the demographic revolution, the fast double "graying" of society especially in developed countries, which rapidly increases the number of elderly within the total population (People aged over 60 will outnumber children aged $0-14$ by 2050). ${ }^{14}$ Combined with a decline in natality and the fact that old people grow older than ever before, this revolution leads to an increase in the need of non-medical care, for which adult children are simply no longer statistically available.

Second: Advanced medical technology contributes to the longevity of frail elderly, who are dependent for their quality of life on specialized geriatric care. This means that old age is increasingly medicalized. Without a constant monitoring by professional expertise, surviving old age in a dignified way is unthinkable. A flexible interplay of both informal and formal care is required for a satisfactory advanced age. Good informal care from family and neighbours depends on the availability of the formal care of professionals, and vice versa. ${ }^{15}$

The distinction between formal and informal care, therefore, becomes increasingly porous and artificial. Family and neighbours are involved and brought in by professionals not only as a resource of care, but also as co-workers and proto-professionals. On the other hand, the moment professional care workers enter homes; they also develop affective and emotional bonds with their clients. Informal caregivers and professionals constantly negotiate "on the spot" how their forms of care relate to one another. One may conclude, with Christine Milligan, that the neo-liberal dislocation of care from public institutions towards home looks like a deinstitutionalizing of care, but in fact represents a movement the other way around: "an institutionalization of the home". ${ }^{16}$

In neo-liberal public health policy's emphasis on home as the place of care, the elder person's self-management (also by calling in the help of one's

14 Cf. the global ageing statistics on HelpAge International's website [Online]. Available: http://www.helpage.org/resources/ageing-data/global-ageing-statistics/.

15 Once involved, professionals sometimes completely take over the household, as in the perception of the care-receivers. They invade the intimacy of the home as a physical space with their own spaces, introducing their signalizing, diagnostic, and monitoring (recently also e-Health) techniques.

16 Milligan, No Place like Home, 23: "The boundaries of home and institution become increasingly porous as the private space of the home becomes transformed into a site of work that care recipients, formal and informal care workers inhabit." 
relatives and neighbours) is considered an integral part of the chain of care in the public health care system. The elderly are kept personally responsible as active subjects for their own health, as long as possible. The focus is on prevention. The frailty of old age in neo-liberal ideology is no longer a matter of fate, but an individual risk.

Seen from a Foucauldian perspective, this policy can be considered rather an expansion of the "medical gaze" than its diminishment. It does not represent a return to an earlier, more "natural" phase in the evolution of human communities, but, on the contrary, an ultramodern political construction. ${ }^{17}$ Christine Milligan describes this development as institutionalisation "without walls". She rather therefore prefers the term extitutionalisation of care. "While the institution has been de-territorialised, it has not been dematerialized." 18

Summarizing my argument thus far, I conclude that the present emphasis on informal care is not a return to the 'natural' organization of elderly care as in the old days, but a next step in the political construction of care. Back to the neighbourhood, back to the family, back home is not a simplification of care, but introduces a new complex, policy driven, topology in the care for elderly.

This politics needs an ideology. Emphasizing the importance of care at home simply needs the idea that home is the best place to be. However, is this true? In the next section, I shall deal with that question.

\section{The best place to be}

The concept "home" is saturated with meanings. In the phenomenology of 'dwelling' and "home" one can distinguish between home as a concrete material reality, the house, and home as a symbol. ${ }^{19}$ The house is, speaking with Augé, a place, distinguished from an abstract, anonymous space that

17 Simon Biggs and Jason L. Powell, "A Foucauldian Analysis of Old Age and the Power of Social Welfare”, Journal of Aging \& Social Policy, 12, no. 2 (2001): 1-20, 4.

18 Milligan, No Place like Home, 143f., resp. 22.

19 For the following, cf. Katherine H. Leith, "Home is where the heart is...or is it? A phenomenological exploration of the meaning of home for older women in congregate housing", Journal of Aging Studies 20, no. 4 (2006): 317-333; Lisa Groger, “A Nursing home can be a home”, Journal of Aging Studies, 9, no. 2 (1995): 137-153; Christine 
is devoid of meaning. ${ }^{20}$ A house with four walls, a roof, windows and a door, represents the physical space that offers you shelter, protection, safety and security against the unpredictability of the elements and the dangers of the strange, outside world. Home is a safe haven. The door is as important as the walls: one feels at home as long as one is in control about who enters as a guest and who has to stay outside.

Home as a symbol however, is strongly connected with one's identity and sense of self. Home is the place where you can express yourself "as you are". Homecoming represents the moment when, or the place where, you are known and loved unconditionally. "Home is, when you knock on the door, they have to take you in." (Robert Frost). Home is like paradise or heaven.

Home as a symbol has also a strong social aspect. Its meaning depends on with whom you live together. During the life course, there are radical social transitions. For children, home is where mother is, where one is nourished and cherished. For young parents, home is the place where you nurture children, and where they start their public performance. For the elderly, home often represents a place of remembrance - and after the loss of a partner - a place of mourning, where pictures and cherished objects refer to a life that lies behind. It offers them a sense of continuity and identity. It is the place where their bodies are nested, and where conventions and routines prevent that their bodies are not being hurt unnecessarily. The meaning of home is often also gender-related. For males, especially those from earlier generations, home often represents a motherly/female space, where their spouses look after men. For women at the contrary, home rather refers to a place of labour and taking care of others. ${ }^{21}$

Home does not always have positive connotations. Many people may associate "home" with domestic violence, emotional negligence, or social isolation. Older men may experience their being homebound as a threat

Milligan, "From home to 'home': situating emotions within the caregiving experience", Environment and Planning 37, no. 12 (2005): 2105-2120.

20 A geographic space becomes a place to which we attach meaning through the significant personal life experiences and social interactions we accumulate there over time. See above, note 10 .

21 Milligan, No Place like Home, 44. 
to their masculinity. ${ }^{22}$ Four walls and a door often symbolize loneliness. Alternatively, for those living in a poor neighbourhood, poverty and unsafety.

"Home" is a complex and variable notion. In addition, the moment caregivers, both informal and formal, enter the home of home dwellers, they change the meaning it has held until then, so that it has to be reconstructed and renegotiated. "I am no longer master in my own home" is a feeling that becomes stronger with the increase of dependency. The physical or digital presence of professional care means loss of control and privacy. First, it is the kitchen, then the living room and the toilet, finally the bed and bathroom that are "taken over". The elderly body still lives at the same place, but it is no longer ... at home. The ambivalence of this new situation becomes even clearer when children, family members, neighbours or volunteers are engaged as, and take on new roles as proto-professionals. ${ }^{23}$

Therefore, the idea that home is the best place to be for the elderly is a misunderstanding. In the background, a $19^{\text {th }}$ century ideal of the nuclear family with its fixed gender roles and private/public dichotomy, may still contribute to the idealization and a romanticizing of family care. Nevertheless, at the least, "home" is an ambivalent notion. In extreme cases, home even turns into a non-place, when it stands for fear, dependency, loss, isolation, or even violence. ${ }^{24}$ Moving to a nursing home sometimes counts as a blessing. ${ }^{25}$

The longing for homecoming probably represents an indelible anthropological universal need. It should therefore be acknowledged and respected. Instead of feeding a - literarily - misplaced nostalgia, it would be preferable to understand homecoming as a future-oriented desire. ${ }^{26}$

22 G. Valentine, "What it means to be a man: the body, masculinities, disability". In Mind and Body Spaces: Geographies of Illness, Impairment and Disability, eds. R. Butler, H. Parr (London and New York: Routledge, 1999), 167-180.

23 Milligan, There's No Place like Home, 75.

24 Milligan, No Place like Home, 73v.

25 Cf. G.C.F. Thomese, "Ouderen knappen op van tehuisopname”, Geron. Tijdschrift over ouder worden en maatschappij, 9 (2007): 21-24.

26 After his analysis of the metaphor 'life as a journey' in $20^{\text {th }}$ century modern literature, Langdon Elsbree concludes that "home no longer exists; that at best there are temporary layovers in the part of the planet where one happens to be; that exile, physical and/or 
Being strangers in exile, as a metaphoric description of its existential characteristic, is not an exception to the human condition, but as the biblical narrative testifies, rather its essence. Theologically, the experience of "home-coming" should therefore be situated in eschatology, instead of in the doctrine of creation. ${ }^{27}$ Paradise never lies behind, but always ahead of us. Together with Abraham and Moses, we are journeying to a "fatherland we have never seen before" (E Levinas). Old age is no exemption of this human condition, but rather its intensification.

\section{The distribution of care responsibilities}

What does this mean for the distribution of care responsibilities? Neoliberal policy claims, seemingly in accordance with human evolution, that those who live in proximity of the elderly take care of them: children, family members, neighbourhood. Having close, "special" relations thus means bearing higher responsibilities. Care responsibilities for frail and dependent elderly should be distributed according to the model of concentric circles: first the children, then the family, then the local community, and finally, the federal government - only if and as far as the family fails to provide elementary care. ${ }^{28}$ Primary responsibility comes to those who are physically close. Here, I want to question this model's apparent evidence on both factual and ethical grounds.

\section{Factually:}

(1) In my first section, I indicated that the geography of care has changed. Care for the elderly is no longer localized at one place, but in a network of physical and virtual spaces. This makes a territorial distribution of care

psychic, may be a permanent condition" (Langdon Elsbree, The Rituals of Life. Patterns in Narrative (Port Washington, N.Y. /London: Kennikat Press, 1982), 39f.). Cf. also Frits de Lange, Heilige Onrust. Een pelgrimage naar het hart van religie (Ten Have: Utrecht 2017), 115ff.

27 "... the Abrahamic-Mosaic adventure is capped by the process of arrival rather than of return.” David James Gauthier, Martin Heidegger, Emmanuel Levinas, and the Politics of Dwelling, PhD Louisiana State University and Agricultural and Mechanical College, 2004, 4. [Online]. Available: https://digitalcommons.lsu.edu/gradschool_dissertations/191/ [Accessed: 1 February 2018].

28 Doreen Massey, “Geographies of Responsibility”, Geografiska Annaler. Series B, Human Geography 86, no. 1 (2004): 5-18: 10. 
responsibilities obsolete. In an electronic and digital society, proximity is organized in a symbolic world, and no longer just physical. When it comes to care or assistance, your next-door neighbour can turn into a stranger, and your Facebook contacts into close friends.

(2) The birth rate in highly industrialized countries has decreased to 2.4 and the number of one-person households is increasing. In emerging economies, the same demographic and sociological processes are taking place, as the standard of living rises. Though the speed of ageing of the population on the southern hemisphere - is slower than in the North, the so-called dependency rate is also increasing on the African continent. ${ }^{29}$ "Ought implies can" is a well-known ethical rule. Morally one cannot require what factually cannot be done. In the case of elderly care: If there are no children, no moral appeal can be made to them.

(3) High life expectancy combined with revolutionary developments in medical technology, make elderly care more complex than ever before. Both health care prevention (nutrition, exercise, medical check-ups) and specialized geriatric care become embedded in technical expert systems that are organized virtually and no longer territorially. Informal care is a visible, but only a limited part of today's health care system.

29 "Fertility decline began more recently in Africa than in the other regions, and thus the proportion of children is starting to fall and the share of working-age persons is beginning to increase, while the proportion of older persons in the population remains fairly small. As a result, the total dependency ratio in Africa is falling gradually, and that decline is projected to continue into the second half of the twenty-first century. The dependency ratio in Africa fell from its peak of 140 dependents per 100 working-age persons in the mid-1980s to 121 dependents per 100 working-age persons in 2015, and is projected to continue to decline to 91 dependents per 100 working-age persons in 2050."

The dependency ratio measures the portion of a population which is composed of dependents (people who are too young or too old to work) and is equal to the number of individuals aged below 15 or above 64 divided by the number of individuals aged 15 to 64, expressed as a percentage. (World Population Ageing 2015, United Nations, New York, 2015, p. 35. [Online]. Available: http://www.un.org/en/development/desa/population/ publications/pdf/ageing/WPA2015_Report.pdf [Accessed: 1 February 2018].

"This process of rapid aging in emerging countries can be described as the 'paradox of development': people live longer, but run a greater risk of falling into old age poverty because family support is declining and this is not being replaced with social security measures at the same rate.' (Caroline E. van Dullemen, The Politics of Aging. The Risk of Old Age Poverty in Emerging Countries, PhD VU Amsterdam 2017, 2, [Online]. Available: http://dare.ubvu.vu.nl/handle/1871/55259 [Accessed: 1 February 2018]. 
Consequently, these facts require an ethical reflection on the distribution of moral responsibilities in the care for the elderly. Let me first clarify my understanding of morality and responsibility. In modern ethics, a theoretical-juridical conception of morality still dominates. The essence of morality is regarded as a form of knowledge that can be reconstructed theoretically. Margaret Urban Walker proposes an alternative, expressivecollaborative vision. In the first model, morality is seen as a kind of code, which orients individuals in their agency. Responsibility can then be expressed accordingly in formulas and applied in rules and procedures. For example: moral theory entails that someone is responsible for a situation deliberately created by him or her, consciously and voluntarily. If none or only one or two of these criteria do apply, a moral subject cannot be held (fully) responsible. The expressive-collaborative approach, however, regards morality not as a form of knowledge, but as a whole of practices within a certain community which functions as "a socially embodied medium of understanding and adjustment in which people account to each other for the identities, relationships, and values that define their responsibilities." 30 The sources of morality can be diverse: certain vocabularies or grammars (words like "irresponsible", "good", "wrong", "promise", "lie" etc.) but also broadly accepted judgments (conventions) or the conduct of exemplary persons can function alike. Moral adjustment happens by arguments, but also by emotions or gestures. Decision-making can occur in freedom, but also through conflicts or as dictated by external authority. Morality, understood as a social and cultural practice, is not only agency-oriented (what should I do?) but also expresses identities (this is me or us) and values (this is what I/we find important). In this approach, morality functions as a distributive code in the allocation of responsibilities, to be negotiated repeatedly. ${ }^{31}$ It is characteristic for ethical practice in democratic societies to strive for dialogical, reasoned, non-violent and just negotiations.

30 " $[\mathrm{T}]$ he expressive-collaborative conception pictures morality as a socially embodied medium of understanding and adjustment in which people account to each other for the identities, relationships, and values that define their responsibilities' (Walker, Moral Understandings, 63)

31 'The materials for assigning responsibilities are given, but exactly how to go on with them, how to make them work in particular cases, and where and how to extend or modify them, may not be' (Walker, Moral Understandings, 62). 
This understanding of morality as a dynamic cultural practice safeguards us from the so-called naturalistic fallacy in the allocation of responsibilities. Even when it may be factually true in the history of humankind that adult children were always responsible for taking care for their frail parents, this does not imply that they are obliged to continue this way, only for the reason that it has been "natural" to do so. Who is responsible for what and when towards whom, is a matter of mutual assessment of all the stakeholders in a particular community. It is the task of ethics to supervise and set rules for a fair negotiation process, without being able to call in some decisive knowledge, or an external authority. Ethical knowledge is not knowledge of principles, which lie ready to be discovered in the moral domain, but of fairness within a cultural practice.

With the so-called "ethics of care" I assumethat care is the most fundamental cultural practice, and that the allocation of care responsibilities therein (who takes care of whom and where?) is a political affair throughout. ${ }^{32}$ In neoliberal societies, the responsibility for specialized medical care is located in mixed public-private arrangements, accessible to those who participate in the social assurance system (in countries with a public health service like the UK, France or the Netherlands) or only for those who can afford it financially (like in the US). Care, in either way, is something you can buy if you are entitled to it. Informal care however, is considered a private responsibility, in practice mostly delegated to women. As the number of elderly with chronic ailments is increasing, this political, ideologically inspired division between informal/private and formal/public care is reaching its practical limits. There is simply more need for informal care than can be delivered privately. Families are expected to behave like protoprofessionals. Often, the informal care workers who are available, collapse under their burden.

Summarizing: Both on factual and moral grounds, I think that the concentric model of the distribution of responsibilities should be reconsidered. It is taken for granted that the geography of responsibilities assumes that care responsibility increases, the closer one lives to the one in need of care. Proximity is the criterion, understood both physically and affectively. Both

32 "The central question for an ethics of care is: How can I (we) best meet my (our) caring responsibilities?” (Tronto, Moral Boundaries, 137). 
connotations are connected. Our family, children, parents etc. are "close" to us because we are or were living close to them. This makes our relationship to them special. In addition, special relationships generate special obligations.

The biblical parable of the Good Samaritan (Luke 10:30-37) breaks with the apparently obvious nexus between affectivity and territory. The Samaritan is an outcast and outsider, a stranger who decides to come physically close to the victim in the ditch, as the priest and the Levite, affectively close to the parable's audience, are taking distance by passing by. However, at the same time, the narrative still seems to emphasize physical proximity as the source of responsibility. The person who finds him- or herself in the neighbourhood of someone in need, is obliged to assist, simply for that reason, as the parable seems to suggest. One enters into a 'special relationship' with a stranger, the moment he or she comes closer physically.

However, is it really proximity - either spatial, emotional or both - that makes the Samaritan responsible? Philosopher Robert E. Goodin defends another position. Against a Kantian-inspired ethics, which entails that the moral law forbids having special relationships, he also upholds that there are indeed "special relationships" with "special responsibilities". Some people are morally closer to us than others are. Goodin's claim, however, is that the special responsibility we have for them is not based on their physical and/or emotional proximity but consists in their vulnerability for specifically our agency. "Special responsibilities derive from the fact that other people are dependent on you and are particularly vulnerable to your actions and choices." ${ }_{33}$ This vulnerability might be caused by the fact that you are, by coincidence, on the spot, and you fortuitously are exactly disposing over the right means to be of help (a lifeboat or lifejacket for a drowning person). However, Goodin's argument also counts for situations where there is no physical or emotional proximity. The only thing that matters is that you, only you and no one else, can help. It is not the proximity, but the dependency that is decisive.

33 Robert E. Goodin, Protecting the Vulnerable. A Reanalysis of Our Social Responsibilities (Chicago and London: The University of Chicago Press, 1985), 33. Compare his formula on p. 118: "If A's interest are vulnerable to B's actions and choices, B has a special responsibility to protect A's interests; the strength of this responsibility depends strictly upon the degree to which B can affect A's interests." 
The responsibility in long-term relationships between frail parents and adult children - people with a common history, which created dependencies for specific needs - becomes understandable this way: though there exists closeness to each other, responsibility here is not based on proximity, but on specific vulnerability. Parents depend on the emotional support of their children, especially when their identities are threatened or damaged by the difficulties of old age. Children confirm and support their parent's narrative identity through physical and affective intimacy, storytelling, by visiting meaningful places together etc. ${ }^{34}$ the care provided this way, not only expresses but also serves to underscore the relationship between parents and children. In sight of death, every role and status seems transient, except the indelibility of parenthood. ${ }^{35}$

What counts between parents and children here is a particular vulnerability and a specific dependency. Other kinds of assistance (financial, administrative, technical, and para-medical) should be provided by those who are specifically accountable for these needs, because they, and only they, have the expertise required to be of help. So not only for family and close community members, but also even for care professionals it applies: "We are all special in some respects". ${ }^{36}$

In conclusion: vulnerabilities and dependencies are not natural givens. They are social constructions, which can change according to time and culture. ${ }^{37}$ In new social practices in the changing landscape of care, care responsibilities must constantly be re-negotiated, and traditional expectations may be challenged on good grounds. The neo-liberal claim that for the elderly home is the best place to be, and that their children have the primary responsibility for taking care of them, is a claim to be contested. Who should care for whom, when and where? The question should be answered in a democratic public dialogue between all those involved, and should not be passed on to individual families or neighbours.

34 Cf. Goodin, Protecting the Vulnerable, 83-89.

35 Walker, Moral Understandings, 91.

36 Walker, Moral Understandings, 99.

37 "Rights and responsibilities in relation to the care of older people operate across a spectrum; with care being located firmly within the family and home at one end of the spectrum, and within the state and institutional settings at the other" (Milligan, No Place like Home, 58). 
In societies that consider the care for children (education, child protection, youth care) as a public responsibility, elderly care should also be considered a public good, for which we bear a collective responsibility.

\section{Bibliography}

Augé, Marc 1995. Non-places. Introduction to an Anthropology of Supermodernity. London-New York: Verso.

Appadurai, Arjun 1996. Modernity at large: Cultural dimensions of Globalisation. Minneapolis: University of Minnesota Press.

Bambra, Clare 2016. Health Divides. Where You Live Can Kill You. Bristol: Policy Press.

Biggs, Simon and Powell, Jason L. "A Foucauldian Analysis of Old Age and the Power of Social Welfare", Journal of Aging \& Social Policy, 12, 2 (2001) 1-20.

Campen, Cretien van, Jurjen Iedema, Marjolein Broese van Groenou \& Dorly Deeg 2017. Langer Zelfstandig. Ouder worden met hulpbronnen, ondersteuning en zorg. Den Haag: Sociaal en Cultureel Planbureau.

Dullemen, Caroline E. van. The Politics of Aging. The Risk of Old Age Poverty in Emerging Countries, PhD VU Amsterdam 2017, 2, [Online]. Available: http://dare.ubvu.vu.nl/handle/1871/55259 [Accessed: 1 February 2018].

Elsbree, Langdon 1982. The Rituals of Life. Patterns in Narrative. Port Washington, N.Y. / London: Kennikat Press.

“Feiten en cijfers over de verpleeghuiszorg, Actiz 2016”. [Online]. Available: https://www.actiz.nl/stream/160715-feiten-en-cijfers-verpleeghuiszorgdef. pdf [Accessed: 1 February 2018].

Gauthier, David James. Martin Heidegger, Emmanuel Levinas, and the Politics of Dwelling, PhD Louisiana State University and Agricultural and Mechanical College, 2004. [Online]. Available: https://digitalcommons. Isu.edu/gradschool_dissertations/191/ [Accessed: 1 February 2018]. 
Global aging is changing the world. WorldGranny report 2004-2016. [Online]. Available: http://www.unightforgranny.nl/wp-content/uploads/2018/05/ Jaarverslag-2004-2016.pdf [Accessed: 1 February 2018].

Goodin, Robert E 1985. Protecting the Vulnerable. A Reanalysis of Our Social Responsibilities. Chicago and London: The University of Chicago Press.

Groger, Lisa. "A Nursing home can be a home”, Journal of Aging Studies, 9, 2 (1995): 137-153.

Hyde Martin and Paul Higgs (eds.) 2016. Ageing and Globalisation. Bristol: Policy Press.

Lange, Frits de. "The Dignity of the Old: Towards a Global Ethic of Ageing”, International Journal of Public Theology 3 (2009): 203-220.

Lange, Frits de 2017. Heilige Onrust. Een pelgrimage naar het hart van religie. Ten Have: Utrecht.

Lawson, Victoria. "Geographies of Care and Responsibility", Annals of the Association of American Geographers, 97, 1 (2007): 1-11.

Leith, Katherine H. "Home is where the heart is ... or is it? A phenomenological exploration of the meaning of home for older women in congregate housing", Journal of Aging Studies 20 (2006): 317-333.

Massey, Doreen. "Geographies of Responsibility", Geografiska Annaler. Series B, Human Geography, 86, 1 (2004), 5-18.

Milligan, Christine 2009. There's No Place like Home: Place and Care in an Ageing Society. Farnham: Ashgate.

Milligan, Christine. “From home to 'home': situating emotions within the caregiving experience", Environment and Planning A 37 (2005): $2105-2120$.

Rubinstein, Robert L. \& Kate de Medeiros, "Successful Aging," Gerontological Theory and Neoliberalism: A Qualitative Critique, The Gerontologist 55, No. 1 (2015): 34-42. 
Thomese, G.C.F. “Ouderen knappen op van tehuisopname”, Geron. Tijdschrift over ouder worden en maatschappij, 9, (2007): 21-24.

Timonen, Virpi 2017. Beyond Successful and Active Ageing. A Theory of Model Ageing. Bristol: Policy Press.

Tronto, Joan 1993. Moral Boundaries. A political argument for an ethic of care. New York: Routledge.

Tronto, Joan 2013. Caring democracy. Markets, equality and justice. New York: New York University Press.

Urban Walker, Margaret 1998. Moral Understandings. A Feminist Study in Ethics. New York and London: Routledge.

Valentine, G. 1999. What it means to be a man: the body, masculinities, disability. In Mind and Body Spaces: Geographies of Illness, Impairment and Disability, R. Butler, H. Parr (eds.), 167-180. London and New York: Routledge.

"Watch. Protection in Old Age. HelpAge International". [Online]. Available: http://www.pension-watch.net/ [Accessed: 1 February 2018].

World Population Ageing 2015, United Nations, New York, 2015, p. 35, [Online]. Available: http://www.un.org/en/development/desa/population/ publications/pdf/ageing/WPA2015_Report.pdf [Accessed: 1 February 2018] 